\title{
Development: Unconventional Monetary Policy on Bank Performance in Nigeria
}

\author{
MENYELIM CHIMA ${ }^{1}$, ABIOLA BABAJIDE ${ }^{2}$, \\ ALEXANDER OMANKHANLEN ${ }^{3}$, BABAFEMI ADEJUMO ${ }^{4}$ \\ ${ }^{1 \& 4}$ Department of Business Administration, Covenant University, P.M.B 1023, Ogun State, NIGERIA \\ ${ }^{2 \& 3}$ Department of Banking and Finance, Covenant University, P.M.B 1023, Ota, Ogun State, NIGERIA
}

\begin{abstract}
The banking system plays an important role in the Environment and Development. This literature explored the influence of unconventional monetary rule on bank financial efficiency, with a vision to analysis to what degree unorthodox monetary expansion would impact deposit money banks' performance using Nigeria as a case study for the developing economies in Africa from (2007-2017). Unorthodox monetary expansion is evaluated via assets of the apex bank to GDP ratio and deposit insured during the period. Using the random effect regression panel data analysis, the findings indicate that unconventional monetary policy is of a negative effect on deposit money bank performance. Further analyses show a negatively expressive relation amid unconventional pecuniary rule and Credit Money Banks performance with regards to deposit insurance coverage. On this basis, this literature principally recommends the apex bank of Nigeria to enact monitory regulations aiming to examine the response of credit finance banks' performance to unconventional measures of monetary policy. The Unconventional Monetary Policy plays an important role in Development.
\end{abstract}

Keywords: Development. Unconventional Monetary Policy, Bank Performance, Net Interest Margin, Panel Regression Analysis.

Received: April 5, 2020. Revised: November 19, 2020. Accepted: December 17, 2020.

Published: December 21, 2020.

\section{Introduction}

The banking system plays an important role in the Environment and Development. The banking system functions as a middleman between the economy's surplus and deficit, which fosters economic growth and development [35], [43]. Monetary economists ' monetary rule offers the mechanism by which monetary regulators control the conduct of the economy, the financial market and banks [19]; [40]; [11]. [1] Opined that a monetary strategy is a tool which includes an optional exertion by the apex financial authority to regulate the money circulation, bank liquidity, inflation and credit situations to accomplish macroeconomic goals. Under standard times, apex banks modify the pace of monetary policy to be injected to the economy through different mechanisms such as Open Market Operations (OMO), money reserve prerequisites, liquid asset proportion, regulation of financial rate (MPR) and ethical persuasion to accomplish the goals of financial guidelines [4], of which a high level of compliance is expected of the Deposit Money Banks. However, in periods of economic slowdown and financial emergency, the traditional monetary policy (expansionary) often utilized by the central bank tends to be constrained in its value due to the zero base bound short term rate guideline. Depending on the severity of the mayhem, traditional monetary policy may not be regarded as impotent [47]. Consequently, apex banks use unorthodox monetary strategy instruments to 
resolve the disruption in the transmission system and fuel aggregate demand and financial markets [41]; [8], and [3], by changing the synthesis of the central banks' financial position through large scale asset purchase [10]; [45];[67]. The impact of unorthodox Method to the competitive sector is less immediate and less evident because the results of such interventions influence macroeconomic conditions implicitly [27]. However, deposit and lending interest rate decreases at figures compelled to nil and lower in accordance with previous observational research [21]; [38]; [45]. Further review of literature, states that noninterest revenue of the banks can be affected negatively and positively as large scale asset purchase causes asset prices to raise hence high yield [61]; [64]. Therefore, unconventional monetary policy can influence bank performance with regards to the capability of banks to entice deposits, issue and maintain performing loans, financially trade and other variables are related. Following the global recession, Nigeria's Central Bank effectively implemented quantitative easing strategy to tackle the question of liquidity scarcity in the banking sector from 2008 through 2010. The monetary stimulus policy steps implemented over the era involved a steady lowering of the regulation for money related rate (MPR) from $10.25 \%$ to $6 \%$ and eventually raised to $6.25 \%$ on 2010 , Reserve fund ratio from 4.0 to $2.0 \%$ and further to $1.0 \%$ while liquidity ratio (LR) was lowered from 40 to $25 \%$; infusion of N620 billion as Tier 2 capital into 8 distressed banks and interbank loan guarantees [60];[17]. Amongst others such as the temporary suspension of mop-up operations; the creation of Asset Management Corporation of Nigeria (AMCON) which commenced full operation in November 2010 and also real sector intervention programs [10]; [12]. Therefore, this study is of the objective to ascertain the extent to which unconventional monetary
policy(UMP) measured by $\mathrm{CBN}$ asset to GDP ratio and the insurance of deposits impacts on the efficiency of Nigerian banks for money deposit based on asset return, equity earnings and Net Margin of interest when accounting for specific bank indicators in Nigeria taking into consideration the pre and post unorthodox monetary stance implementation in the Nigerian financial sector using the panel data regression analysis. Although there is a considerable empirical evidence of the greater economic effects of eccentric financial policies [10]; [70]; [27]. Less amount of research has evaluated the U.M.P on the financial progress of bank for money deposit in developing economies [39]; [48]; [45]. However, in developing countries including Nigeria, the influence of unconventional monetary measures on deposit money banks performance has not been concentrated upon in research. Studies in Nigeria have only considered monetary policy on economic growth and bank performance [4]; [52]; [49]; [55]. Based on this premise, bridging the gap in present literature, by studying the extent to which untraditional monetary stance influence deposit fund banks financial efficiency in this geographical region will aid the monetary authorities, the banking industry and other financial stakeholders in developing nations and the world to implement hedging strategies to cushion against the nontraditional monetary policy impact. The subsequent part of this paper consists of the theoretical underpinning, conceptual and empirical discuss of prior studies, and the next part will deal with the methodology followed by the interpretation of results and then summary, conclusion and recommendation respectively.

\section{Literature Review}

\subsection{Theoretical Framework}




\subsubsection{Monetarists' Economic Theory}

The banking system plays an important role in the Environment and Development. [28] promulgated the monetarist hypothesis as a result of the Keynesian hypothesis criticism. Conversely, the importance of money related policy as buttressed by [29] is the ability to affect the volume, cost and course of the money supply. The monetarist is of the assumption that inflation is consistently and in every way, a monetary economic situation. He perceived that in the near term increment in cash stream can decrease joblessness; however, can likewise result in inflation; thus, the money supply should be cautiously increased by the monetary authorities. Monetarist theory embraced the equation of trade by Fisher to represent their hypothesis. The import of this condition is that if the economic fund supply increases so will the value level [4]. The fisher's condition expresses that: $\mathrm{MV}=\mathrm{PQ}$

Where: $\mathrm{M}=$ cash supply in the economy; $\mathrm{V}=$ speed of circulation; $\mathrm{P}=$ value level in the economy; and $\mathrm{Q}=$ output created by the economy.

Monetarists like [28]; [29] underlined cash supply as the main component influencing the prosperity of the economy. The cash supply should therefore be developed at a fixed rate, rather than managed and modified by the financial authority, so as to advance the pace of growth. He also contended that because cash supply is substitutive for securities as well as for some merchandise and ventures, changes in cash supply will in this manner, have both immediate and aberrant impacts on expenditure and speculation separately. The monetarists are persuaded that the modification of the currency supply directly contributes to a change in the actual amount of cash. Monetarists believe that the apex bank can have an impact on the actual part of the economic system by the operations of O.M.O. [4].

\subsection{Conceptual Framework}

Economies around the world implement a monetary policy with the fundamental target to make a stable macroeconomic condition for the stability of the economy. The accomplishment of this target relies upon whether money related policy activities penetrate the economic real sector [40]. Channels through which money related policy can be injected into the economic real sector are the obligation 'instruments (interest rate) or asset purchase which affects the stock costs [47]. Customary money related policy has a constraint: the zero lower transient rates of interest [66] and this is not a sign of a barren money related policy, as it is relative to the level of deepening of the crisis [47]. Because of the worldwide financial issue and the resulting profound worldwide economic downturn, central banks far and wide including Nigeria pushed their regulatory rates to the near zero and commenced the implementation of U.M.P of acquiring vast amounts of the assets when money related regulatory rate is compelled by the nil base bound of the official transient costs of interest. A nonstandard monetary stance raises the volume of capital within the monetary framework and drives lower rates throughout the economic system by furnishing money related entities and money markets with enormous cashflow when the national bank's very own short run rate regulation is at or almost nil [67].

There are two unique ways to deal with unconventional money related policies. The first is a successive methodology that is chiefly utilized by the Federal Reserve, Bank of Japan and Bank of England. Assuming, the interest nominal pace diminishes and gets to near-zero unorthodox monetary guidelines are utilized to give additional stimulation. In a 
New-Keynesian system, instigating inflation through increasing the financial position might diminish genuine rates [70], which can improve investment. In the subsequent methodology utilized for the most part by European Central Bank, during an emergency, Unorthodox money related policy is utilized simultaneously with customary money related strategy before interest cost gets closer to null in other to fix the interruptions in the instruments of transmission [62]. This reduces the outcome of the rates bound to nil on the economy and its agents.

\subsubsection{Bank Performance}

The variables and facets that decide Deposit Money Banks' financial performance have been discussed by a number of authors [7]; [56]; [37] and [65]. For the most part, these elements are partitioned into two wide classes, external factors (macroeconomics elements) and explicit bank elements (microelements). Operational elements are explicit with each bank as they can be impacted by the interior administration and top managerial staff. The banks' administration has no control of macroeconomics elements that emerge in the macroeconomics domain, for example, inflation rate, interest cost rate, conversion scale, and other money-related policy instruments and industry guideline announcements by the money related authority.

While financial proportion formulae are the techniques frequently used to assess firm performance, there is no obvious method of reasoning which would enable one to obtain a composite score on the altogether money related soundness of a firm [44]. Two expansive methodologies are commonly utilized in writing to clarify bank performance, and they are structural and nonstructural. Non-structural methodologies pick distinctive performance measures (for example ROE, ROA, net premium margins,
Tobin's q-ratio, etc.), and clarify these indicators by an arrangement of bank peculiar or entity components. Basic or systemic methodologies depend on banking conduct hypothetical concepts, for example, expense minimization or benefit optimization [33]. Cost minimization is a basic rule used by banks and financial institutions to produce output at the lowest cost and this influences profit maximization and organizational performance in general.

\subsubsection{Unconventional Monetary Policy and Bank Performance}

The literature on the causal association between UMPs and bank financial strength is somewhat constrained. It is vital to comprehend the impact of non-standard money related policies on the loan financing costs that banks charge borrowers, in an attempt to evaluate the link between the UMPs and net margin of interest.

In reference to the 'Samuelson effect' developed by Samuelson in 1945, [45] assessed that when financing cost rates are low, banks' incomes from loan advances diminish, while interest costs for banks' from lodgments do not diminish in a similar degree since banks' portfolio comprise principally of deposit of transaction and call deposit. Hancock (1985) express that a rise in loan costs lifts the profitability of banks, as loan rate sensitivity is greater than the rate of deposit elasticity. Following past discoveries [13]; [26]; [38] on UMPs, especially through Large Scale Asset Purchase, causes loaning interest costs to decline. Thus, would lower the net premium margin and influence bank performance adversely. In [22] study, a decline in interest rate instability over nontraditional monetary stance era could have a favourably link between the margin of interest and the bank benefits, of which 'zerolow limits effect' can be responsible for a drop in the degree of interest instability. 
The monetary bank performance likewise relies upon non-premium revenue that stems from the commerce of money related assets which could be influenced by Unconventional financial policy. Banks incorporate into their portfolio advances and different assets, for example, financial instruments, assets, and market options owned. At a favourable level, buying by central banks will trigger portfolio prices to rise via the channel' portfolio balance' [61]; [64]. With this reality, banks are encouraged to utilize these money possessions to buy high yield assets, for example, equity and bond securities [61]; [64]. Over the long haul, bulk asset purchases decrease the market vulnerability and lift the market players' trust in economic forecasting [69]. However, in actuality, through the 'signalling' channel the central bank buys may show that monetary and economic possibilities would fall apart and this may negatively affect asset costs and benefits from the portfolio with banks [20].

Eccentric money related rules could also influence bank financial output through its effect on the financing charge of banks. [39] suggested that banks could profit under the almost nil policy rate, which could diminish the expense of lodgement financing. However, Institutional financiers restrain banking establishments by pegging of larger interest rate than a customer with smaller deposits [15]. During this policy period, an increased degree of depositors funds are insured and commercial banks adequate liquidity is guaranteed by the central bank thereby reducing the risk of loss.

Until this point, the connection between deposit protection inclusion and bank performance has been debated by present literature. From one viewpoint, guaranteed depositors may charge reduced lodgment rates because of indemnity coverage [23]; [58]. A decrease in lodgment rates owing to insurance protection would prompt reduced funding expenses, thus raising interest margin of banks' (the subtraction of loaning from lodgment rates) and accordingly, bank financial efficiency. Without deposit protection, the private depositors will resort to the monitoring of banks; hence, uninsured investors could request an increase in lodgment rates [9]; [24], prompting a decrease in net premium margins consequently influencing money related performance. It should be noted that the decrease in net premium margin could be aggressive for uninsured banks in agreement with [9]; this is so as uninsured investors are strict with banks by charging higher deposit interest costs.

Besides, with the influence of lower interests over unorthodox money related policy periods, protected banks tend to loosen up further on their credit guidelines as a result of the absence of private observation and hence promotes loaning to the clients of low financial soundness [16]; [34]. With respect to the above assessments, this may prompt an increase in nonperforming loans that could bring about banks underperformance [2].

\subsection{Empirical Literature Review}

Several empirical scholars [18]; [53]; [25]; [50]; [52]; [57];[6]; [49], have completed studies to diagnose the relationship and how monetary policy affects DMBs' performance and operations. However, a few scholars have studied the Unorthodox monetary policy impacts on bank efficiency [45]; [39]; [48].

[25] inspected the influence of money related policy on the financial productivity of Nigeria's banking sector policy within the medium of 1970 to 2006 . The paper utilized specific determinants and the ordinary least square (OLS) system. Outcomes demonstrated that money-related policy significantly affects the liability of deposits. Notwithstanding, explicitly it was found that Deposit Rate (DR) and Minimum Discount Rate (MDR) affect 
the lodgment liabilities of the bank in Nigeria, while Exchange Rate (EXR) impacted the Nigerian banks' lodgment liabilities. Hence, they inferred that money-related policy assumes a crucial job in deciding the amount of Nigerian banks' account liabilities.

[51], explored the effect of money related policy on Vietnamese deposit money banks' profitability. Information was gathered from 20 listed Vietnamese deposit money banks over the duration 2007 to 2014; regression of panel data was utilized. Money related base (MB), discount rate (DIS) and required reserve proportion (RRR) were utilized as intermediaries for money related policy. Benefit before tax was utilized to speak to the performance of business banks'. The outcomes demonstrated an affirmative connection between the profit of banks and money related policies. In the assessment of the Apex Bank of Nigeria's (CBN) monetary policy instruments before and during the bank recapitalization process (2000-2016) and assessing the impact of these policy methods on the financial results of Nigerian commercial banks (DMBs) using the Autoregressive Lag Model (ADL) to analyse data sourced through the Statistical report of the CBN, 2016, [4] proved that the CBN's monetary policies had a huge influence on the short-term success of DMBs, but had a negligible long-run effect. Leveraging on individual-level data of home-covered Securities (MBS), and analyzing quantitatively how unorthodox monetary stance affects MBS spreads. [66], finds that the United States Federal Reserve and the Bank of Japan adoption of unorthodox monetarist policies have major statistical causality for MBS margin reduction. In the further probe, evidence suggests that the market-based approach of the Federal Reserve to unorthodox monetary policy is successful in reducing MBS spreads by offering based financial aid to the MBS industry in the United States, while the Japanese apex bank unorthodox monetary policy tactic via financial support through commercial banks is also said to reduce MBS spread.

In respect to the limited evidence on the interaction between UMPs and performance of the bank, [45] explores the connection between unorthodox monetarist policy and efficiency of the US banking industry. Using panel data regression, the results show an adverse association between unorthodox money related policy and bank efficiency. Further analysis shows that for banks with strong diversification of asset and minimaldeposit financing, the negative association between untraditional money related policy and financial output is mitigated. The research also showed that the adverse linkage between unorthodox quantitative easing and efficiency is implicit for financial entities that are protected on the account. [39] noticed that throughout the duration of 2007Q3 and 2012Q3, UMP had a detrimental effect on bank efficiency. [48], however, noticed that UMP only improved the competitiveness of big US banks. [36] analyzed the effects of the unorthodox monetary rule of the European Central Bank (ECB) on the availability and efficiency of bank loans regarding the eurozone and exposed the ECB's restricted capacity to improve the efficacy of the banks ' lending system and influence the competitiveness of banking institutions throughout the downturn. From the above empirical review, it can be observed that the study on UMPs and bank financial efficiency is restricted and concentrated amongst the developed economies. Therefore, considering the fact that this study has not been done in Nigeria as a developing economy, this report attempts to develop UMP's relationship with Nigerian deposit bank performance as a contribution to the frontier of academic knowledge by introducing apex bank asset to GDP proportion as a proxy of UMP which captures the total asset held by the Nigerian 
apex bank as a GDP share which incorporates real non-financial domestic industry.

\section{Methodology}

\subsection{Data}

To establish the hypothesis test for this research, data are sourced and analysed from annual reports of sampled monetary banks for deposit, the Central Bank of Nigeria and the Nigerian Stock Exchange (NSE) website. The study was limited to 10 deposit money banks listed on the N.S.E in the time frame of 20072017 extracting a total of 110 observations that encompass the pre and post-economic recession era.

\subsection{Variable Measures}

\subsubsection{Unconventional Monetary Policies}

A number of authors have attested to the apex bank balance sheet as a proxy for unconventional money related policy [70]; [30]; [31]. The central bank of Nigeria's balance sheet rose in the third quarter of 2011 by $91.1 \%$ and $23.46 \%$ in 2012 [10] which was after achieving quantitative easing from 2008 to 2010. According to [45], large scale acquisition of asset results in an increase in the balance sheet of the federal reserves on both the asset and liability side. This study used apex bank's assets to GDP ratio as a proxy of UMP. Also, to determine the efficiency of banks whose deposits were insured during the period, the study used Nigeria Deposit Insurance Coverage (NDIC), bank-specific dummies shall be used to the extent of 0 if bank deposits are not protected by the NDIC and 1 if bank deposits are protected by the NDIC.

\subsubsection{Firm Performance}

The firm efficiency would be calculated by way of accounting-based metrics. Enterprise value reflects the satisfaction of returns received by stakeholders include staff, administrators, shareholders, creditors, public and government under value-focused management [42]. The accounting-based performance using the Return on assets, which is the periodic earnings relative to the total asset used to generate operating cash flow. Net interest margin is also known as Interest rate spreads (IRS- the ratio of interest income and interest expense to overall reserves for financial institutions) [63].

\subsubsection{Control Variables}

This paper controls for banking -specific factors such as size natural logarithm of real total assets The latest scientific literature is mixed regarding the association between size and bank results [22]; shareholders equity ratio (equity/total assets) which shows the fraction of total asset funded by the shareholders' equity and $\mathrm{z}$ score depicting credit risk in a nation's financial sector, measured as a weighted sum of each bank's zscores in Nigeria (weights are dependent on the overall assets of each bank). Z-score measures the reserves of a bank (capitalisation and yields) to the uncertainty of such returns [63].

\subsection{Statistical Analysis}

To test the formulated hypotheses, multiple linear regression test will be used in this research to scrutinize the influence of unconventional money rule and firm efficiency. Static regression estimators such as ordinary least square, fixed and random effect will be used. The OLS model disregards the panel dataset by merging the construct on the variables. Nevertheless, the difference in the 
coefficient is ignored, which rejects probable heterogeneity. Studies propose that underlining expectations are impractical. Meanwhile, fixed effect and random effects are more suitable for static panel data. The error term of the fixed effect specification assumes a constant variance over time and serially uncorrelated while the random effect specification controls for heterogeneity [14]. This study will then apply the Hausman test to select the most suitable estimators between fixed and random effects. The regression model is stated below:

\subsubsection{Static Regression Model}

Perf $_{i, t}=\beta_{0}+\beta_{1}$ Policy $_{i, t}+\beta_{2}$ Equity $_{\text {TA }}+\beta_{i, t}+\beta_{3}$ Zscore $_{i, t}+\beta_{4}$ Size $_{i, t}+\varepsilon_{i, t}$ (1)

Where:

$t=$ the annual year for firm $i$

Perf $=$ the financial performance proxied by; Return on Asset ( net profit after tax/ shareholders' equity); Return of Equity (net profit after tax/ total assets); Net Interest Margin (interest income minus interest expenses)

Equity/TA $=$ Total Equity/Total Asset

$Z$ score $=$ Weighted average of the z-scores of a country's individual banks

Policy $=$ Unconventional monetary policy proxied by the central bank's asset to GDP ratio and deposit insurance coverage.

Size $=$ the natural logarithm total assets of the firm

\section{Firm}

Performance

ROA

ROE

$109 \quad 0.016$

0.021

$-0.095$

0.056

ROE

109

0.092

$\begin{array}{ll}0.276 & -2.251\end{array}$

0.550

Net Interest

109

7.810

0.387

6.818

8.703

Margin

\section{Independent \\ Variables}

CBN asset to

GDP

NDIC

11

$\begin{array}{ll}0.273 & 0.447\end{array}$

0.923

5.434

110

2.201

1.466

0

1

\section{Bank specific \\ Level \\ $\begin{array}{llllll}\text { Equity/TA } & 109 & 0.137 & 0.189 & -1.548 & 1\end{array}$ \\ $\begin{array}{llllll}\text { Z score } & 110 & 16.462 & 2.208 & 12.784 & 20.06\end{array}$ \\ Size}

This section details the findings from Table 15 and discussions. Table 1 contains the definition of variables and variables of descriptive statistics. From the Table, The accounting-based performance has a max value of $5.57 \%$ and a min value of $-9.53 \%$. The equity earnings (ROE) is 0.2764 on the average. Also, the net interest spread has a max value of 8.703 and 6.818 as its minimum value. For the independent variable, $\mathrm{CBN}$ asset to GDP ratio has a maximum of 5.434 and minimum of 0.923 . The NDIC is a dichotomous variable that has a mean of $27.27 \%$ with a standard deviation of $44.7 \%$. In the aspect of the bank-specific level, equity/TA has an average of $18.89 \%$; $\mathrm{Z}$ score has an average of 2.208 while that of bank size is 0.3885 on the average. Table 2 presents the correlation coefficients between variables. The table presents a low correlation between the variables. Hence, there exists no multicollinearity statistical problem in the models.
Table 1: Descriptive Statistics

\begin{tabular}{llllll}
\hline VARIABLES & $\mathrm{N}$ & Mean & S. D & Min. & Max. \\
\hline
\end{tabular}


Table 2: $\quad$ Correlation Matrix

\begin{tabular}{|c|c|c|c|c|c|c|c|c|}
\hline & 1 & 2 & 3 & 4 & 5 & 6 & 7 & 8 \\
\hline 1.ROA & 1 & & & & & & & \\
\hline 2.ROE & $0.71^{* * *}$ & 1 & & & & & & \\
\hline 3.Margin & $0.26^{* *}$ & $0.29^{* *}$ & 1 & & & & & \\
\hline $\begin{array}{l}\text { 4.CBN asset } \\
\text { to GDP }\end{array}$ & -0.07 & 0.05 & 0.13 & 1 & & & & \\
\hline 5.NDIC & -0.05 & $-0.23^{*}$ & $-0.26^{* *}$ & $-0.19^{*}$ & 1 & & & \\
\hline 6.equityTa & $0.56^{* * *}$ & 0.07 & -0.00 & -0.17 & $0.22^{*}$ & 1 & & \\
\hline 7.Zscore & -0.01 & -0.13 & $-0.33^{* * *}$ & 0.03 & $0.66^{* * *}$ & 0.08 & 1 & \\
\hline 8.Size & $0.30^{* *}$ & $0.25^{* *}$ & $0.84^{* * *}$ & 0.14 & $-0.31^{* *}$ & 0.17 & $-0.36^{* * *}$ & 1 \\
\hline
\end{tabular}

Table 3- 5 reports the OLS, fixed and random effect regression. However, due to the limitation of OLS regression in financial performance researches, the emphasis of this literature is based on fixed and random effect regression.

Table 3 demonstrates the influence of unorthodox money related policy on asset yield and expresses the outcome of OLS, the fixed and random effect regression. Moreover, the Hausman test suggests that random outcome regression is more fitting for inference of the result at a $p$-value of 0.6889 with $\mathrm{R}^{2}=0.326$. This means that encompassing both control variables and the unconventional monetary policy proxies explain $33 \%$ of the Return on assets. From the table, CBN asset to GDP ratio is negative but not significant on Return on assets. The negative coefficient could signal an adverse effect on Return on assets. Market participants may perceive the central bank of Nigeria acquisitions as an indication of financial weakness that could negatively alter the financial market valuation of the asset and thus lead to the deposit money banks' investment losses (signalling effect) [20]; [45]. Furthermore, the insignificant effect could be due to the contraction in the net interest margins based on low-interest premium, which can be well explained by the Samuelson effect. The result infers that the impact of the unconventional money related rule using the NDIC proxy is significantly negative on the Return on Asset at 0.05 significance point. By virtue of the proof that protected banks are prone to loosen up on their credit guidelines as a result of the absence of private observation and hence promote loans to debtors who lack financial soundness [16]; [34]. This may prompt a higher credit nonpayment rate that could bring 
about banks underperformance [2]. In economic magnitude, this result suggests that the execution of untraditional money related rules will decrease the level of Return on assets.

Table 3: Unconventional Monetary Policy and Return on Asset

\begin{tabular}{|c|c|c|c|}
\hline & OLS & $\begin{array}{l}\text { Fixed } \\
\text { Effect }\end{array}$ & $\begin{array}{l}\text { Random } \\
\text { Effect }\end{array}$ \\
\hline \multirow{2}{*}{$\begin{array}{l}\text { CBN asset to } \\
\text { GDP }\end{array}$} & -0.000748 & -0.000569 & -0.000699 \\
\hline & $(0.00117)$ & $(0.00104)$ & $(0.00103)$ \\
\hline \multirow[t]{2}{*}{ NDIC } & $-0.0112 * *$ & $-0.00991 * *$ & $-0.0101 * *$ \\
\hline & $(0.00514)$ & $(0.00445)$ & $(0.00445)$ \\
\hline \multirow[t]{2}{*}{ EquityTa } & $0.0606 * * *$ & $0.0533 * * *$ & $0.0547 * * *$ \\
\hline & $(0.00920)$ & $(0.00832)$ & $(0.00824)$ \\
\hline \multirow[t]{2}{*}{ banksZscore } & 0.00168 & 0.000949 & 0.00127 \\
\hline & $(0.00104)$ & $(0.000993)$ & $(0.000948)$ \\
\hline \multirow[t]{2}{*}{ Size } & $0.0107 * *$ & 0.00281 & 0.00701 \\
\hline & $(0.00471)$ & $(0.00780)$ & $(0.00632)$ \\
\hline \multirow{2}{*}{ Constant } & $-0.113 * *$ & -0.0286 & -0.0718 \\
\hline & $(0.0486)$ & $(0.0789)$ & $(0.0642)$ \\
\hline Observations & 109 & 109 & 109 \\
\hline R-squared & 0.379 & 0.326 & 0.326 \\
\hline RMSE & 0.0168 & 0.0145 & 0.0145 \\
\hline F-test & 12.57 & 9.088 & \\
\hline Prob $>F$ & 0.0000 & 0.0000 & \\
\hline chi-squared & & & 52.45 \\
\hline Prob $>$ chi 2 & & & 0.0000 \\
\hline Hausman Test & & & 3.07 \\
\hline Prob $>$ chi 2 & & & 0.6889 \\
\hline
\end{tabular}

Standard errors in parentheses $* * * \mathrm{p}<0.01, * *$

$$
\mathrm{p}<0.05, * \mathrm{p}<0.1
$$

Table 4 illustrates the influence of unconventional money related policy on the yield on Equity and presents the outcome of OLS, the fixed and random effect regression. Moreover, the Hausman test suggests that random effect regression is better designed for inference of the result at a p-value of 0.7959 with $\mathrm{R}^{2}=0.066$. This means that encompassing both control variables and the unconventional monetary policy proxies explain $6.6 \%$ of the Return on Equity. From the table, CBN asset to GDP ratio on the yield on equity is unfavourable but insignificant. The negative coefficient shows that central bank asset to GDP ratio could have an adverse effect on equity return. This is akin to the result of UMP on return on assets and also consistent with [36]. There are tendencies that the banks may not have efficiently utilized or managed their capital. The result infers that the outcome of the unconventional money related stance using the NDIC proxy is considerably negative on the Return on Equity at 0.1 significance point. This reflects the same result to that of the influence of deposit insurance on Asset Return, and the result is consistent with [36]. In economic magnitude, this result indicates that the implementation of unconventional money related rules will decrease the level of Return on Equity as through increased assets purchases by the bank of authority causes a depressed interest return and depicts a signal of a diminishing financial potential for the Nigerian deposit banks.

Table 4: Unconventional Monetary Policy and Return on Equity

\begin{tabular}{lccc}
\hline & OLS & $\begin{array}{c}\text { Fixed } \\
\text { Effect }\end{array}$ & $\begin{array}{c}\text { Random } \\
\text { Effect }\end{array}$ \\
\hline CBN asset to & -0.00380 & 0.00166 & -0.00380 \\
GDP & & & \\
& $(0.0187)$ & $(0.0180)$ & $(0.0187)$ \\
NDIC & $-0.161^{*}$ & $-0.136^{*}$ & $-0.161^{*}$ \\
& $(0.0821)$ & $(0.0774)$ & $(0.0821)$ \\
Equity/TA & 0.120 & -0.0260 & 0.120 \\
& $(0.147)$ & $(0.144)$ & $(0.147)$ \\
Zscore & 0.0137 & -0.00456 & 0.0137 \\
& $(0.0166)$ & $(0.0173)$ & $(0.0166)$ \\
Size & $0.141^{*}$ & -0.0701 & $0.141^{*}$ \\
& $(0.0752)$ & $(0.136)$ & $(0.0752)$ \\
Constant & $-1.378^{*}$ & 0.839 & $-1.378^{*}$
\end{tabular}




\section{$(0.777) \quad(1.371) \quad(0.777)$}

\begin{tabular}{lccc} 
Observations & 109 & 109 & 109 \\
R-squared & 0.100 & 0.066 & \\
RMSE & 0.268 & 0.251 & 0.268 \\
F-test & 2.293 & 1.335 & \\
Prob $>$ F & 0.0509 & 0.256 & \\
chi-squared & & & 11.46 \\
Prob $>$ chi2 & & & 0.0429 \\
Hausman Test & & & 5.57 \\
Prob $>$ chi2 & & & 0.7959 \\
\hline
\end{tabular}

Standard errors in parentheses $* * * \mathrm{p}<0.01, * *$ $\mathrm{p}<0.05, * \mathrm{p}<0.1$

Table 5 expresses the influence of unconventional money related stance on Net Interest spread, which offers the analysis test of OLS, the fixed effect, and random effect regression. From the table, CBN asset to GDP ratio is negative and not significant on Net Interest Margin. The negative coefficient designates that CBN asset to GDP ratio could have a detrimental effect on the net interest rate. This could be due to the contraction in the net interest margins based on low-interest premium, which can be well explained by the Samuelson effect. Further investigation into the impact of UMP on the profitability of banks reinforces the presence of a negative linkage, as there is a fall in the longstanding rate of interest and, hence, the gap between the anchor rate and the interest rate on loans [38]. Because of the reported greater sensitivity of the lending cost in comparison with the lodgment rate, reducing interest rates on loans could contribute to a quicker decline in income than interest costs arising from deposits [36]; [32] therefore, profits are depressed. However, the result infers That Unorthodox money related policy has a positive but insignificant impact using the NDIC proxy on the Net Interest Margin. The positive coefficient designates that NDIC could be an effective way to improve the bank interest profitability; market players regard
UMP as an infusion of capital into deposit financial institutions and assume an implied promise of their adequate results [48]. Therefore, the findings say the implementation of the unorthodox monetary rule has little or no influence on the level of Net Interest Margin.

Table 5: Unconventional Monetary Policy and Net Interest Margin

\begin{tabular}{lccc}
\hline & OLS & $\begin{array}{c}\text { Fixed } \\
\text { Effect }\end{array}$ & $\begin{array}{c}\text { Random } \\
\text { Effect }\end{array}$ \\
\hline CBN asset to & -0.00267 & -0.00500 & -0.00267 \\
GDP & & & \\
& $(0.0144)$ & $(0.0145)$ & $(0.0144)$ \\
NDIC & 0.0603 & 0.0559 & 0.0603 \\
& $(0.0632)$ & $(0.0623)$ & $(0.0632)$ \\
EquityTa & $-0.337^{* * *}$ & $-0.287^{* *}$ & $-0.337^{* * *}$ \\
& $(0.113)$ & $(0.116)$ & $(0.113)$ \\
BanksZscore & -0.00752 & -0.00130 & -0.00752 \\
& $(0.0127)$ & $(0.0139)$ & $(0.0127)$ \\
Size & $0.873^{* * *}$ & $0.958^{* * *}$ & $0.873^{* * *}$ \\
& $(0.0579)$ & $(0.109)$ & $(0.0579)$ \\
Constant & 0.0707 & -0.808 & 0.0707 \\
& $(0.598)$ & $(1.105)$ & $(0.598)$ \\
& & & \\
Observations & 109 & 109 & 109 \\
R-squared & 0.729 & 0.581 & \\
Rmse & 0.207 & 0.203 & 0.207 \\
F-test & 55.34 & 26.04 & \\
Prob $>$ F & 0 & 0 & \\
chi-squared & & & 276.7 \\
Prob $>$ chi2 & & & 0 \\
\hline
\end{tabular}

Standard errors in parentheses *** $\mathrm{p}<0.01,{ }^{* *} \mathrm{p}<0.05,{ }^{*} \mathrm{p}<0.1$

\section{Conclusion}

The banking system plays an important role in the Environment and Development. The intent of this research is to evaluate the interaction of 
unconventional money related stance regime on deposit money banks pecuniary performance in Nigeria as no vivid literature bridging this gap in the literature in this geographical area. Unconventional monetary policy was factored by Nigeria's central bank assets to GDP ratio and the Nigerian deposit insurance commission as an autonomous factor, and output of deposit fund banks was proxied by Asset Return, Equity Return and Net Interest spread as the explained variable. Pooled, fixed and random impact regression was implemented and analysed in this study. However, the Hausman test showed that the most effective is the random effect regression. The findings show that there exists a negative influence between the UMP on bank performance which is consistent with [45]; [36]; [38].

This article presents first-time proof of the UMP's impact on the efficiency of depositing money banks in an emerging nation such as Nigeria. Regardless of the fact that Unorthodox monetary policy is a series of steps taken by the monetary authority to put an end to an extraordinary economic condition when traditional monetary policy tools (interest levels, minimum reserves, free market activity) seem to exhibit limitations in producing the expected result. The research offers proof of the Central Bank of Nigeria's limited capacity to influence the bank's financial results throughout the UMP time, and this is in tandem with [45] and [38] for financial institutions in the United States and [36] for samples across European countries. This is due primarily to the reduced rate and often negative throughout the UMP era.

According to the outcome, which indicates an unfavourable interaction between the $\mathrm{CBN}$ asset to GDP ratio and Equity Returns, Assets Return , net interest margin; the insured deposits' negative influence on Equity Return, Asset Return and a positive linkage with the net interest margin. The study recommends the apex bank of Nigeria to intensify its focus on bank quality while the bank administration and regulatory agencies should incorporate the repercussions of unorthodox monetary policy into consideration. In this regard, bank regulation should be strengthened so as to intently observe bank financial efficiency reaction to unorthodox money related stances. The apex bank of Nigeria should implement the unorthodox monetary rule in parallel with the traditional monetary rule in other to prevent the Samuelson effect, which can impair the banks' performance. In addition, for banks that have low levels of diversification of resources and those dependent on deposits, this evaluation can be used as an information feed-back for policy decisions. Lastly, this study should inspire authors to evaluate the impact of UMP on the efficiency of the bank using the dynamic panel estimation model in Nigeria and other nations to further attest to the findings of this paper.

\section{Acknowledgement}

This research was made possible by the Covenant University Centre for Research, Innovation and Discovery (CUCRID). The writers of this paper are immensely grateful for the monetary support for this publication. And the anonymous reviewers who strengthened the work with their suggestions.

\section{Reference.}

[1] Abata, M.A., J.S. Kehinde and S.A. Bolarinwa, Fiscal/Monetary policy and economic growth in Nigeria: A theoretical exploration. International Journal of Academic Research in Economics and management Science, 1(5): 2012, pp. $75-88$.

[2] Abreu, M.and Mendes, V., Commercial bank interest margins and profitability: evidence from EU countries. Porto Working Paper Series, CISEP, Portugal, 2002.

[3] Acharya, V., Eisert, T., Eufinger, C., and 
Hirsch, C., Whatever it takes: The real effects of unconventional monetary policy. SAFE Working Papers, (152), 2016.

[4] Adesina, J. B., Nwidobie, M. B., and Amadi, A. N., Monetary policy and financial performance of nigerian deposit money banks. European Journal of Business and Management, 7(17), 2015. https://doi.org/10.18488/journal.aefr.2018. $\underline{87.853 .869}$

[5] Adesina, J. B., Nwidobie, M. B., and Amadi, A. N., Monetary policy and financial performance of nigerian deposit money banks. Asian Economic and Financial Review, 8(7), 2018, pp. 853869.

https://doi.org/10.18488/journal.aefr.2018. 87.853 .869

[6] Ajayi, F.O. and A.A. Atanda, Monetary policy and bank performance in Nigeria: A two - Stepcointegration approach. African Journal of Scientific Research, 9(1), 2012, pp. 462-476. View at Google Scholar.

[7] Al - Tamini, H.H.A., Factors Influencing performance of the UAE Islamic and Conventional National Banks, Department of Accounting and Finance and Economics, College of Business Administration, University of Sharjah, 2010.

[8] Altavilla, C., Giannone, D.,and Lenza, M., The financial and macroeconomic effects of OMT announcements (No. 10025). CEPR Discussion Papers, 2014.

[9] Anginer, D., Demirguc-Kunt, A., and Zhu, M., How does deposit insurance affect bank risk? Evidence from the recent crisis. J. Bank. Financ. 48, 2014, pp.312-321.

[10] Armstrong, A., and Ebell, M., Unconventional Monetary Policy: Introduction. National Institute Economic Review, 234(1), 2015, pp. 1-4. https://doi.org/10.1177/002795011523400 $\underline{101}$

[11] Ayopo, B. A., Isola, L. A., and Olukayode, S. R., Monetary policy dynamics and the stock market movements: Empirical evidence from Nigeria. Journal of Applied Economic Sciences, 10(8), 2015.

[12] Babajide A. A., Olokoyo, F.O., and Adegboye, F.B. "Bank failure prediction in Nigeria: A survival analysis approach" In Proceedings of the 22nd International Business Information Management Association Conference, IBIMA 2013 Creating Global Competitive Economies: 2020 Vision Planning and Implementation, (Rome; Italy; 13 -14 November 2013), Volume 3, 2013, pp. 2180-2199

[13] Bauer, M., and Rudebusch, G., Monetary policy expectations at the zero lower bound. Federal Reserve Bank of San Francisco Working Paper, 18, 2013.

[14] Boudriga, A., Taktak, B. N. and Jellouli, S. Bank Specific, Business and Institutional Environment Determinants of Banks Nonperforming Loans: Evidence from MENA Countries, Working Papers 547, Economic Research Forum, revised 09 Jan 2010.

[15] Calomiris, C., Building an incentivecompatible safety net. J. Bank. Financ. 23, 1999, pp. 1499-1519.

[16] Carapella, F., and Di Giorgio, G., Deposit insurance, institutions, and bank interest rates. Transit. Stud. Rev. Vol. 11, 2004, pp. 77-92.

[17] CBN, Central bank monetary policy committee; cbn communique no. 59 of the monetary policy committee (MPC) meeting, held $11^{\text {th }}$ of December, Abuja, Nigeria, 2008.

[18] Chigbu, E. and Njoku, M., The impact of monetary and fiscal policies on Nigerian economic growth: $1990-2010$. European Journal of Business and Management, 5(2), 2013, pp. 13- 24.

[19] Chortareas, G., and Noikokyris, E., Monetary policy and stock returns under the MPC and inflation targeting. International Review of Financial 
Analysis,Vol. 31, 2014, pp. 109 - 116.

[20] Christensen, J., and Rudebusch, G., Modeling yields at the zero lower bound: are shadow rates the solution? Working paper, 2013.

[21] D’Amico, S., English, W., LópezSalido, D., and Nelson, E., The Federal Reserve's large-scale asset purchase programmes: rationale and effects. Econ. J. (London) Vol. 122, 2012, pp. 415-446.

[22] De Guevara, J., and Maudos, J., Explanatory factors of market power in the banking system. Manch. Sch. Vol. 75, 2007, pp. 275-296.

[23] Demirguc-Kunt, A., and Huizinga, H., Market discipline and deposit insurance. $J$. Monet. Econ. Vol. 51, 2004 pp. 375-399.

[24] Demirguc-Kunt, A., and Kane, E., Deposit insurance around the globe: where does it work? J. Econ. Perspect. Vol. 16, 2002, pp. 175-195.

[25] Ekpung, G.E., Udude, C.C. and Uwalaka, H.I. The impact of monetary policy on the banking sector in Nigeria. International Journal of Economics, Commerce and Management, 3(5), 2015, pp. 1015- 1031.

[26] Fawley, B., and Neely, C., Four stories of quantitative easing. Federal Reserve Bank of St. Louis Review, 95(January/February 2013).

[27] Fiorelli, C., and Meliciani, V., Economic growth in the era of unconventional monetary instruments: A FAVAR approach. Journal of Macroeconomics, 2019, pp. 1-20. https://doi.org/10.1016/j.jmacro.2019.01.0 $\underline{04}$

[28] Friedman, M., The quantity theory of money - a restatement. In studies in the quantity theory of money. Chicago: University Chicago Press. 1956, pp: 277 290.

[29] Friedman, M., Money and business cycles. Review of Economics and Statistics, 45(1), 1963, pp. 32 - 64.
[30] Gambacorta, L., Hofmann, B., and Peersman, G., The effectiveness of unconventional monetary policy at the zero lower bound: a cross-country analysis. J. Money Credit Bank. Vol. 46, 2014, pp. 615-642.

[31] Greenwood, R., and Vayanos, D., Price pressure in the government bond market. Am. Econ. Rev. Vol. 100, 2010, pp. 585-590.

[32] Hancock, D.L., Bank profitability, interest rates, and monetary policy. $J$. Money Credit Bank. Vol. 17, 1985, pp. 189-202.

[33] Hughes, J. P., and Mester, L. J., Measuring the Performance of Banks: Theory, Practice, Evidence, and Some Policy Implications. In SSRN Electronic Journal. 2013 , https://doi.org/10.2139/ssrn.2306003

[34] Ioannidou, V., and Penas, M., Deposit insurance and bank risk-taking: evidence from internal loan ratings. J. Financ. Intermed. Vol. 19, 2010, pp. 95-115.

[35] Isaac, L., Appraising the Impact of Budgeting and Planning on the Performance of Financial Institutions in Nigeria. Research Journal of Finance and Accounting, 5(16), 2014, pp.12-27.

[36] Kenourgios, D. and Ntaikou, D., ECB's unconventional monetary policy and bank lending supply and performance in the euro area. Journal of Economics and Finance. 2019, pp. 1-14. 10.1007/s12197019-09503-6.

[37] Khan, W.A. and Sattar, A., Impact of interest rate changes on the profitability of four major commercial banks in Pakistan. International Journal of Accounting and Financial Reporting, 4(1), 2014, pp.142154.

[38] Krishnamurthy, A. and, VissingJorgensen, A., The effects of quantitative easing on interest rates: channels and implications for policy. National Bureau of Economic Research. (No. w17555). 
2011.

[39] Lambert, F. and Ueda, K., The effects of unconventional monetary policies on bank soundness. International Monetary Fund. 2014, No. 14-152.

[40] Laopodis, N.T., Monetary Policy and Stock Market Dynamics across Monetary Regimes. Journal of International Money Finance, Vol. 33, 2013, pp. 381-406. www.elsevier.com/locate/jimf.

[41] Lenza, M., Pill, H., and Reichlin, L., Monetary policy in exceptional times. Econ. Policy 25 (62), 2010, pp. 295-339.

[42] Liu, X., and Zhang, C. Corporate governance, social responsibility information disclosure, and enterprise value in China. Journal of Cleaner Production, Vol. 142, 2017, pp. 10751084.

https://doi.org/10.1016/j.jclepro.2016.09.1 $\underline{02}$

[43] Lupu, I., The Indirect Relation between Corporate Governance and Financial Stability. Procedia Economics and Finance, 22(November 2014), 2015, 538-543.https://doi.org/10.1016/S22125671(15)00254-3

[44] Madanoglu, M., Kizildag, M., and Ozdemir, O., Which bundles of corporate governance provisions lead to high firm performance among restaurant firms? International Journal of Hospitality Management, 72(December 2017), 2018, pp. 98-108.

[45] Mamatzakis, E., and Bermpei, T. What is the effect of unconventional monetary policy on bank performance? Journal of International Money and Finance, Vol. 67, 2016, pp. 239-263. https://doi.org/10.1016/i.jimonfin.2016.05. $\underline{005}$

[46] Mishkin, F. S., is monetary policy effective during financial crisis? NBER Working Papers, no. 14678, 2009.

[47] Mishkin, F., The Transmission Mechanism and the Role of Asset Prices.
Monetary Policy, Working Paper 8617. 2001 http://www.nber.org/papers/w8617.

[48] Montecino, J., and Epstein, G., Have large scale asset purchases increased bank profits? Institute for New Economic Thinking, working paper series no. 5, 2014.

[49] Ndubuaku, C. N, Ozioma, I., Chiaka, N., and Samuel, O., Impact of Monetary Policy ( Interest Rate) Regimes on the Performance of the Banking Sector in Nigeria. $\quad 8(4), \quad 2017, \quad 16-32$. https://doi.org/10.9790/5933-0804011632

[50] Ndugbu, M.O. and P.A. Okere, Monetary policy and performance of deposit money banks - the Nigerian experience. European Journal of Business and Management, ISSN 2222-1905 (Paper) ISSN 2222-2839 (Online) 7(17) 2015, 65-72.

[51] Nguyen, N.V.H. and H.T. Le, Impacts of monetary policy on commercial banks' profits: The case of Vietnam. Asian Social Science, 13(8) 2017, pp. 32- 40.

[52] Nwannebuike, S. Impact of Monetary Policy Instruments on Profitability of Commercial Banks in Nigeria: Zenith Bank Experience. Research Journal of Finance and AccountingOnline), 6(10), 2015, pp. 2222-2847.

[53] Okoye, V. and Eze, R.O., Effect of bank lending rate on the performance of Nigerian deposit money banks. International Journal of Business and Management Review, 1(1) 2013, 34- 43.

[54] Olokoyo, F.O., Determinants of commercial banks' lending behaviour in Nigeria. International Journal of Financial Research, 2(2), 2011, pp. 61 72.

[55] Omankhanlen, A. E., Peter, D., Senibi, E. J., Isibor, A., and Okoye, L. Monetary policy and stock market development: The nigeria experience. Paper presented at the Proceedings of the 33rd International Business Information Management 
Association Conference, IBIMA 2019: Education Excellence and Innovation Management through Vision 2020, 2019, pp.9803-9811. Retrieved from www.scopus.com

[56] Ongore, V.O. and G.B. Kusa, Determinants of financial performance of commercial banks in Kenya. International Journal of Economics and Financial Issues, 3(1), 2013, pp. 237-252.

[57] Onodugo, I.C., Okoro, O.E.U., Amujiri, B.A. and Onodugo, V.A., Impact of monetary policy on performance of commercial banks in Nigeria. 2016.

[58] Peria, M., and Schmukler, S., Do depositors punish banks for bad behavior? Market discipline, deposit insurance, and banking crises. J. Finance 56, 2001, pp. 1029-1051.

[59] Samuelson, P., The effect of interest rate increases on the banking system. Am. Econ. Rev. 35, 1945, pp. 16-27.

[60] Sanusi, S. L., Global financial meltdown and the reforms in the Nigerian banking sector, CBN Journal of Applied Statistics, ISSN 2476-8472, The Central Bank of Nigeria, Abuja, Vol. 2, Iss. 1, 2011, pp. 93-108

[61] Tobin, J., An Essay on the Principles of Debt Management. Cowles Foundation for Research in Economics at Yale University. 1963.

[62] Uchida, M., Towards the end of deflation in Japan? Monetary Policy under Abenomics and the Role of Central Bank,\| Reveue de l'OFCE- Analyse et previsions, no. 135, 2014, pp. 243-257.

[63] Udom, I. S., Agboegbulem, N. T. I., Atoi, N. V, Adeleke, A. O., Abraham, O., Onumonu, O. G., \& Abubakar, M. Modelling banks ' interest margins in Nigeria. CBN Journal of Applied Statistics, 7(1), 2016, pp.1-26.

[64] Vayanos, D., and Vila, L., A preferredhabitat model of the term structure of interest rates. National Bureau of
Economic Research. (No. w15487), 2009.

[65] Wainaina, Effect of macroeconomic factors on Commercial Banks Lending to Agricultural Sector in Kenya. MBA Project University of Nairobi. 2013.

[66] Wang, L. Measuring the effects of unconventional monetary policy on MBS spreads: A comparative study. North American Journal of Economics and Finance, 49 (October,2019), pp. 235-251. https://doi.org/10.1016/j.najef.2019.03.020

[67] Wang, L., Unconventional monetary policy and stock repurchases: Firm-level evidence from a comparison between the United States and Japan. Research in International Business and Finance, 51, 2020 , 101091 https://doi.org/10.1016/j.ribaf.2019.10109 $\underline{1}$

[68] World Bank, Bank Z-Score for Nigeria [DDSI01NGA645NWDB], retrieved from FRED, Federal Reserve Bank of St. Louis; https://fred.stlouisfed.org/series/DDSI01N GA645NWDB, November 17, 2019.

[69] Wright, J., What does monetary policies do to long-term interest rates at the zero lower bound? Econ. J. (London) Vol. 122, 2012, pp. 447-466.

[70] Y1lmaz, D., and Ertü, E., The Unconventional Monetary Policy: A Theoretical Approach The Unconventional Monetary Policy: A Theoretical Approach. $\quad 2017$. https://doi.org/10.18178/ijtef.2017.8.2.546

\section{Authors' Contribution}

Menyelim Chima gathered the data, defined the methodology, analyzed the data and did recommendations and conclusion.

Abiola Babajide was responsible for supervising the study and references.

Omankhanlen Alexander was responsible for proof-reading and editing the work. 


\section{Babafemi Adejumo carried out the introduction and literature review. \\ Sources of funding for research presented}

This research was made possible by the Covenant University Centre for Research, Innovation and Discovery (CUCRID).

\section{Creative Commons Attribution License $\quad 4.0 \quad$ (Attribution $\quad 4.0$ International, CC BY 4.0)}

This article is published under the terms of the Creative Commons Attribution License 4.0 https://creativecommons.org/licenses/by/4.0/d eed.en_US 